\title{
Research on Industrial Safety Evaluation Model under the Restriction of Resources and Environment
}

\author{
Ning Guoyu \\ School of Economics and Management, \\ Northwest University,229 Taibai N. Rd.Xi'an, \\ Shaanxi,China 710069
}

\author{
Zhao Jingfeng \\ School of Economics and Management, \\ Northwest University,229 Taibai N. Rd.Xi'an, \\ Shaanxi,China 710069
}

\begin{abstract}
In the current, global economy is facing resources and environment constraints increasingly strong, under the background, low carbon economy and green development become a trend. Industrial safety is becoming one of the hot issues of concern of many scholars, including that of Industrial Safety Evaluation Index System becoming research focus. Therefore, this study on the basis of domestic and industrial security assessments, considering the ecological balance, resource constraints, environmental pollution and other factors and promote the sustainable development of our industry. Through analysis includes external security and industrial industry internal security, external security mainly refers to external control industry, competitiveness and external dependence, the internal security is the basis of internal industry influence industry and sustainable self-development and other factors of on, by taking expert scoring and analytic hierarchy process (AHP) combined approach to building the index system and model resource and environmental constraints of industrial safety assessment, and by comparing longitudinal and transverse compare overall judgment of a State in which the industrial safety the overall state and propose certain measures for its future development.
\end{abstract}

Keywords-Global Resources ; Environment Constraints ; Industrial Safety Indicators; Assessment Model; industrial security

\section{INTRODUCTION}

The international wide attention on the country's economic security issues began in the end of the 20th century, and it has been widespread concern in government, academia, whether developed or developing, or national markets for the maintenance of their national interests, adhere to the country's economic sovereignty, enhance participation competitive purposes, gradually this factor into industrial safety in national strategic or government decisions, and the trend has continued to strengthen. China's current economy is facing energy consumption continues to grow, further increasing environmental pollution, international trade in greenhouse gas emissions need to take responsibility and pressure will be increasing, faced with the supply of resources, pollution, ecological environment and trade of carbon emission constraints have become increasingly severe, which added a little uncontrollable factors as Chinese industry against foreign risks, but also cause more serious impact to some extent on the security of China's industrial development. Therefore, in the increasingly tight resource and environmental constraints of the situation, to build industrial safety evaluation system, which is not only conducive to the construction and improvement of the domestic industry, the system of economic theory, and further enhance the industrial development of theoretical guidance for national economic development; and is conducive to enhancing sustainable development of our national economy, and enhance international competitiveness, and so has important theoretical and practical significance.

\section{B ASIC FRAMEWORK AND MODEL OF}

INDUSTRIAL SAFETY EVALUATION SYSTEM UNDER RESOURCE AND ENVIRONMENTAL CONSTRAINTS

In the study of industrial security issues, While we need to clear the connotation of industrial safety, which means under conditions of economic globalization, domestic industries can withstand unfavorable factors at home and abroad to maintain a balanced industrial development through a variety of ways, either by the supply of resources in the development process ${ }^{[2]}$; On the other hand, we need to sort out in advance on the basis of research, that is $\mathrm{He}$ (2008) systematic and testability industrial safety evaluation index system research; Department of Commerce Bureau of Industry Injury Investigation (2008) and Jin (2006) Improve safety assessment of traditional industries, further complement the impact of government's macro policies on industrial safety. Xu (2008) and easy name, Wang (2007),respectively,ecosystems and resource constraints from the perspective of proposed industrial safety evaluation index system for industrial safety evaluations provide new ideas and methods ${ }^{[3]-[6]}$. Zhang Kai et al. (2012) from the perspective to build a low-carbon industrial safety evaluation system, discusses the impact of environmental pollution and resource supply constraints on carbon emissions in industrial safety, and social security from the industrial, economic security and ecological safety of three aspects to build analysis ${ }^{[7]}$. Against pollution and global warming increasingly ecological environment, more and more scholars began to focus on the supply of resources and ecological environment, thus believe that the supply of resources, environmental pollution and greenhouse gas emissions 
has become an important factor affecting the industrial security ${ }^{[8]-[9]}$. Therefore, we should consider the ecological balance, resource constraints, environmental pollution and other factors and promote the sustainable development of our industry. Also, industrial safety should specifically include external security and industrial industry internal security, external security mainly refers to external control industry, competitiveness and external dependence, industry internal security refers sustainability industry and the internal influence their own development. Based on comprehensive consideration of the content and impact of industrial safety factors, we constructed the index system and model resource and environmental constraints of industrial safety assessment.

\section{A. Industrial safety evaluation index system}

According to industry security content, in accordance with scientific and comprehensive combining, scalability and practicality combined qualitative and quantitative indicators, principles of short-term and long-term industrial safety industrial safety combination ${ }^{[0]}$, based on the perspective of resource and environmental constraints, we build industrial safety assessment system (see Table 2), including industrial and domestic development environmental Assessment (S1), industrial Sustainable Development Capacity assessment (S2), the international competitiveness of industry assessments (S3), external dependence industry assessment (S4) and industrial control assessment (S5) in five areas.

TABLE 1 INDUSTRIALSAFETY EVALUATION SYSTEM UNDER THE PERSPECTIVE OF RESOURCES AND ENVIRONMENTAL.

\begin{tabular}{|c|c|c|c|}
\hline \multirow{37}{*}{$\begin{array}{l}\text { Industrial } \\
\text { safety } \\
\text { evaluation } \\
\text { index } \\
\text { system }\end{array}$} & Evaluation & Influence factors & Quantifiable indexes \\
\hline & \multirow{9}{*}{$\begin{array}{c}\text { Industrial domestic } \\
\text { development } \\
\text { environment } \\
\mathrm{S}_{1}\end{array}$} & \multirow{7}{*}{$\begin{array}{l}\text { Market environment } \\
\qquad \mathrm{S}_{11}\end{array}$} & Domestic market demand growth rate $\mathrm{X}_{1}$ \\
\hline & & & Domestic market share $\mathrm{X}_{2}$ \\
\hline & & & Industrial concentration $\mathrm{X}_{3}$ \\
\hline & & & Related industrial competitiveness $\mathrm{X}_{4}$ \\
\hline & & & Labor cost $\mathrm{X}_{5}$ \\
\hline & & & Capital cost $\mathrm{X}_{6}$ \\
\hline & & & Human capital $\mathrm{X}_{7}$ \\
\hline & & \multirow{2}{*}{$\begin{array}{l}\text { Government regulation } \\
\text { environment } S_{12}\end{array}$} & Chinese government performance evaluation index $\mathrm{X}_{8}$ \\
\hline & & & The proportion of industrial policy number $\mathrm{X}_{9}$ \\
\hline & \multirow{6}{*}{$\begin{array}{c}\text { Industrial } \\
\text { sustainable } \\
\text { development } \\
\text { capacity } \mathrm{S}_{2}\end{array}$} & \multirow{3}{*}{$\begin{array}{l}\text { Resource consumption and reuse } \\
\qquad \mathrm{S}_{21}\end{array}$} & Energy consumption per unit of output value $X_{10}$ \\
\hline & & & value added per unit of output water consumption $X_{11}$ \\
\hline & & & Resource recycling rate $\mathrm{X}_{12}$ \\
\hline & & \multirow{3}{*}{$\begin{array}{l}\text { Pollutant emissions } \\
\qquad \mathrm{S}_{22}\end{array}$} & Sewage emissions per unit of output $\mathrm{X}_{13}$ \\
\hline & & & Gas emissions per unit of output $\mathrm{X}_{14}$ \\
\hline & & & Carbon emissions per unit of output $\mathrm{X}_{15}$ \\
\hline & \multirow{11}{*}{$\begin{array}{c}\text { Industrial } \\
\text { international } \\
\text { competitiveness } \mathrm{S}_{3}\end{array}$} & \multirow{8}{*}{$\begin{array}{l}\text { Industrial reality competitiveness } \\
\qquad \mathrm{S}_{31}\end{array}$} & Total industrial output value $\mathrm{X}_{16}$ \\
\hline & & & Industrial profit margin $\mathrm{X}_{17}$ \\
\hline & & & Labor productivity $\mathrm{X}_{18}$ \\
\hline & & & Return on assets $X_{19}$ \\
\hline & & & The number of patent ownership $\mathrm{X}_{20}$ \\
\hline & & & The proportion of R \& D expenditure in the cost $X_{21}$ \\
\hline & & & Innovative product profitability $\mathrm{X}_{22}$ \\
\hline & & & The proportion of professionals $X_{23}$ \\
\hline & & \multirow{3}{*}{$\begin{array}{c}\text { International trade } \\
\text { competitiveness } \\
\mathrm{S}_{32}\end{array}$} & Trade competitiveness index (TSC) $\mathrm{X}_{24}$ \\
\hline & & & Revealed comparative advantage index (RCA) $\mathrm{X}_{25}$ \\
\hline & & & International market share $\mathrm{X}_{26}$ \\
\hline & \multirow{5}{*}{$\begin{array}{c}\text { Industrial external } \\
\text { dependence } \\
\mathrm{S}_{4}\end{array}$} & Export dependence $\mathrm{S}_{41}$ & Industrial export external dependence $\mathrm{X}_{27}$ \\
\hline & & Import dependence $\mathrm{S}_{42}$ & Industrial import external dependence $\mathrm{X}_{28}$ \\
\hline & & Capital dependence $\mathrm{S}_{43}$ & Industrial capital external dependence $\mathrm{X}_{29}$ \\
\hline & & Technology dependence $\mathrm{S}_{44}$ & Industrial technology external dependence $\mathrm{X}_{30}$ \\
\hline & & Energy dependence $\mathrm{S}_{45}$ & Industrial energy external dependence $\mathrm{X}_{31}$ \\
\hline & \multirow{5}{*}{$\begin{array}{l}\text { Industrial control } \\
\mathrm{S}_{5}\end{array}$} & Market control $S_{51}$ & Foreign market share $X_{32}$ \\
\hline & & Technical control $\mathrm{S}_{52}$ & Foreign technical control rate $X_{33}$ \\
\hline & & Brand control $\mathrm{S}_{53}$ & Foreign brand share $X_{34}$ \\
\hline & & Equity control $\mathrm{S}_{54}$ & Foreign equity control rate $\mathrm{X}_{35}$ \\
\hline & & Country control $\mathrm{S}_{55}$ & Foreign country concentration $\mathrm{X}_{36}$ \\
\hline
\end{tabular}




\section{1)Industrial domestic development environmental evaluation}

Domestic Domestic development environment is the basis for the survival of the industry, including the impact of a financial environment, environmental factors of production, market demand environmental and industrial policy environment for the development of industrial safety and so on. From the market environment $\left(\mathrm{S}_{11}\right)$ and government regulation environment $\left(S_{12}\right)$ two aspects of the industry were evaluated domestic development environment, including the domestic market demand growth $\left(\mathrm{X}_{1}\right)$, the domestic market share $\left(\mathrm{X}_{2}\right)$, industrial concentration $\left(\mathrm{X}_{3}\right)$, Related industrial Competitiveness $\left(\mathrm{X}_{4}\right)$, labor costs $\left(X_{5}\right)$, capital costs $\left(X_{6}\right)$, human capital $\left(X_{7}\right)$, the Chinese Government performance Assessment Index $\left(\mathrm{X}_{8}\right)$ and the proportion of the number of industrial policy $\left(\mathrm{X}_{9}\right)$ nine quantifiable indicators.

2) Industrial sustainable development capacity evaluation

Industrial sustainable development capacity is the guarantee for the industry to obtain long-term competitive advantages.From resource consumption $\left(S_{21}\right)$ and environmental pollution $\left(S_{22}\right)$ both to examine the capacity for sustainable development of the industry, including the energy consumption per unit of output $\left(\mathrm{X}_{10}\right)$, the added value of water consumption per unit of output $\left(X_{11}\right)$, resource recycling rate $\left(X_{12}\right)$, water emissions per unit of output $\left(\mathrm{X}_{13}\right)$, the amount of emissions per unit of output $\left(\mathrm{X}_{14}\right)$ and carbon emissions per unit of output $\left(\mathrm{X}_{15}\right)$ and six other quantifiable indicators.

\section{1) Industrial international competitiveness} evaluation

Industrial international competitiveness is the comparative productivity of one country's particular industry relative to foreign competitors, reflecting the international market share and profitability of the products of the industry. Our comprehensive evaluation index and industrial needs on the basis of safety assessments of existing international competitiveness of the industry, we use industry output $\left(X_{16}\right)$, Profit Margin $\left(X_{17}\right)$, labor productivity $\left(\mathrm{X}_{18}\right)$, return on assets $\left(\mathrm{X}_{19}\right)$, the number of patents ownership rate $\left(\mathrm{X}_{20}\right), \mathrm{R} \& \mathrm{D}$ expenditure as a percentage proportion of the cost $\left(\mathrm{X}_{21}\right)$ Innovative product profitability $\left(\mathrm{X}_{22}\right)$ and proportion of professional personnel $\left(\mathrm{X}_{23}\right)$ and other indicators to measure the competitiveness of the industrial reality $\left(S_{31}\right)$, with the trade competitiveness index (TSC) $\left(\mathrm{X}_{24}\right)$, revealed comparative advantage index (RCA) $\left(\mathrm{X}_{25}\right)$ and international market share $\left(X_{26}\right)$ to measure industrial competitiveness in international trade $\left(S_{32}\right)$, which constitute the industrial international competitiveness evaluation.

\section{2) Industrial external dependence evaluation}

The primary indicator of the external dependence mainly reflects the degree of dependence of the industry on international markets and the negative impact brought by transnational factors. Industrial external dependence and industrial survival safety degree change in the opposite direction, namely, the higher the industrial external dependence, the more susceptible to transnational negative factors, the lower the industrial survival safety degree.External dependence Industry $\left(\mathrm{S}_{4}\right)$ including industry export dependence on foreign $\left(\mathrm{X}_{27}\right)$, industry's dependence on foreign imports $\left(\mathrm{X}_{28}\right)$, industry's dependence on foreign capital $\left(\mathrm{X}_{29}\right)$, industry's dependence on foreign technology $\left(X_{30}\right)$ and the dependence on foreign energy industry $\left(X_{31}\right)$ and other five indicators.

\section{3) Industrial control evaluation}

Industrial control index mainly assesses the influence and control degree of foreign capital on the safety of industry, and this paper uses foreign capital equity control $\operatorname{rate}\left(\mathrm{X}_{32}\right)$, foreign capital technical control $\operatorname{rate}\left(\mathrm{X}_{33}\right)$, foreign capital brand share $\left(\mathrm{X}_{34}\right)$, foreign capital country concentration $\left(\mathrm{X}_{35}\right)$ and foreign capital market $\left(\mathrm{X}_{36}\right)$ share to reflect this aspect.

\section{B. Industrial safety evaluation Method and model}

\section{1 ) Industrial safety evaluation method}

About industrial safety indicators processing method can generally be divided into two types ${ }^{[11]-[13]}$ : First, the industrial safety indicators approach divided into three categories, namely for the completion of indicators and predictive self-learning functions, such as self-averaging regression method, DEA model etc; for complete screening and classification of indicators, such as regression analysis, factor analysis and the like; and more integrated indicators and targets weight distribution is very important step, which are commonly used quantitative methods with a conventional multi-index integrated approach, AHP (AHP), etc ${ }^{[14]}$., but due to the quantitative analysis of these methods it is difficult to operate, in the safety evaluation of the outcome of the current industry has not use these methods to determine the weight of each index. Second, the commonly used is an expert score, there is a big subjectivity to some extent, thereby affecting the accuracy of the industrial safety evaluation results ${ }^{[15]}$.Therefore, this article draw on previous research, according to research needs, using first score on the basis of expert on the use of the Analytic Hierarchy Process (AHP) to study.

\section{2) Industrial safety evaluation model}

Based on the above Industrial safety evaluation method and index system, we initially construct the following industrial safety evaluation model:

$$
S=f\left(S_{1}, S_{2}, S_{3}, S_{4}, S_{5}\right)=a S_{1}+b S_{2}+c S_{3}+d S_{4}+e S_{5}
$$

$$
\begin{aligned}
\text { And, } S_{1} & =\sum w_{i} s_{1 i} \\
S_{2} & =\sum x_{j} s_{2 j} \\
S_{3} & =\sum y_{k} s_{s k} \\
S_{4} & =\sum z_{l} s_{4 l} \\
S_{5} & =\sum v_{m} s_{5 m} \\
(i, j, k & , l, m=1,2,3,4,5) \\
a & +b+c+d+e=1 \\
\sum w_{i} & =\sum x_{j}=\sum y_{k}=\sum z_{l}=\sum v_{m}=1
\end{aligned}
$$

Among them, $\mathrm{S}$ is the industrial safety degree; $\mathrm{S}_{1}$ is the industrial domestic development environmental evaluation value; $S_{2}$ is the industrial sustainable development capacity 
value; $S_{3}$ is the industrial international competitiveness evaluation value; $S_{4}$ is the external dependence evaluation value; $S_{5}$ is the industrial control evaluation value; $a, b, c$, $\mathrm{d}$ and $\mathrm{e}$ is respectively the coefficient of primary index $S_{1}$, $\mathrm{S}_{2}, \mathrm{~S}_{3}, \mathrm{~S}_{4}$ and $\mathrm{S}_{5} ; \mathrm{S}_{1 \mathrm{i}}, \mathrm{S}_{2 \mathrm{j}}, \mathrm{S}_{3 \mathrm{k}}, \mathrm{S}_{41}$ and $\mathrm{S}_{5 \mathrm{~m}}$ is respectively the corresponding secondary indicator under each primary indicator; $w_{i}, x_{j}$ and $y_{k}$ is respectively the coefficient of secondary indicators.

\section{CONCLUSION}

On the basis of the establishment of evaluation index system and evaluation model, we can divide the industrial safety state into security, basic security, insecurity and crisis or divide into a number of security levels. We can compare the comprehensive index value of the comparison year with the comprehensive index value of the base period through the longitudinal comparison, and can also compare the comprehensive index value of the country with the comprehensive index value of other countries through the horizontal comparison, so as to determine the overall state of the country's industrial safety .

Nowadays, Today, whether in domestic or international, supply of resources, environmental pollution, ecological destruction and greenhouse gas emission constraints and other factors of industrial development is increasing, it can not be underestimated, and therefore the ecological safety of industrial safety as an evaluation is essential of. From the overall situation model and evaluation system, the measure of resource consumption and pollution emissions does not conflict with other quantitative indicators, and has a certain relevance. Thus, after the addition of the ability to indicators of sustainable development of the industry in the industrial safety assessment system, make industry more perfect safety measure, thus more conducive to sustainable development and competitiveness of the industry. Of course, given the resource supply "environmental pollution and greenhouse gas emissions constraints on their industrial development plays a decisive role, we need further consideration in the future when building scientific and effective industrial safety quantitative evaluation system, we need to industry Safety evaluation of future trends, dynamic process of industrial safety evaluation, industry type, etc. to differentiate different designs for a strong program..

\section{REFERENCES}

[1] HE Weida.National economic security and development in the context of globalization[M].Beijing:Machinery Industry Press, 2012 edition from 36 to 88 .

[2] ZHU Jian-min,WEI Da-peng. The construction and demonstration of the country's industrial safety evaluation system $[\mathrm{J}]$, Research management, 2012 (6) 45 - 48.

[3] WU Qi. Chinese Provincial Energy Efficiency Evaluation Study [D]. Dalian:Dalian University of Technology, 2010.

[4] MI Qiang,MI Juan.A Primary Study on Index System of Energy Conservation of China[J].Ecological economy, 2010 (2): 58-61.

[5] BAI Yun-bu.Study on environmental regulation background resource-based industries development[D].Xi'an:Northwestern University, 2013:88-91

[6] XU Ming-yan,HUANG Zu-hui.The Origin of Natural ResourceBased Industrial Cluster-A "Game" Analysis Based on Regional Effect and Agglomeration Effect[C]. International Conference on Engineering and Business Management(EBM2012) . 2012-03-26.

[7] ZHANG Kai,HE Wei-da, NIU Chong-shan.Build low-carbon perspective of industry safety evaluation system[J] Productivity Research, 2012 (12): 68-70.

[8] FANG Qiao-ling, LIU Changcui,XIAO Zhen-dong.Expenditure Performance Evaluation System Construction of Environmental Protection [J] Auditing Research, 2010 (5): 22-27.

[9] YANG Tao.Business Environment Evaluation System Construction - Comparative Analysis Based on the four provinces of Shandong, Jiangsu, Zhejiang,Guangdong[J].Commercial Economic Research, 2015 (13): 28-31.

[10] ZHU Meng.Government Performance Audit Evaluation Index System and Application of Environmental Construction - A Case Study of Water Environmental Improvement Project[D]. Changchun:Jilin University, 2015:101-112.

[11] ZANG Zhi-biao.China Ecological Security Dynamic Model Construction and Evaluation manufacturing environment[J] Modern Management Science, 2014 (8): 60-62 .

[12] DU Wen-jiao,REN Da-peng.Security Guarantee of Agriculture Industry Based on the Improvement of Legal System of Peasant Specialized Cooperative[J].Asian Agricultural Research.2011(3) : 112-117.

[13] WANG Yan-zhen,ZHAO Qing-jian. Water Evaluation Method and Evaluation Index System of Environmental Safety Construction [J] Beijing City University, 2014 (4): 65-70.

[14] HE Xiu-ying.County Investment Environment Evaluation System Construction of Liaoning Province $[\mathrm{J}]$ technology and the market, 2014 (9): 292-293 + 295.

[15] WANG Xiao-li.Special funds for environmental protection Performance Audit Evaluation System Construction of China[D] Tsingtao:China Ocean University, 2014:99-103. 